\title{
Differences of methacrylate and silorane based composite resins surface hardness after $40 \%$ hydrogen peroxide application
}

\author{
Amalina Putri*, Rahmi Alma Farah Adang*, Opik Taofik Hidayat* \\ *Department of Conservative Dentistry Faculty of Dentistry Universitas Padjadjaran
}

\begin{abstract}
Composite restoration is frequently found on teeth before doing any bleaching treatment. Hydrogen peroxide is a bleaching agent which enable transition to one of the composite physical properties. The aim of this research was to observe the difference of surface hardness between methacrylate and silorane based composite resin after application of $40 \%$ hydrogen peroxide. This true experiment involved 36 specimens from two different disc-shaped methacrylate and silorane based composite resins, with 18 specimens methacrylate and 18 silorane. Every specimen groups were immersed in artificial saliva solution and divided into two groups; the first group consisted of 9 specimens of control which were tested directly using microvickers hardness tester and another group consisted of 9 specimens which had been added by $40 \%$ hydrogen peroxide for hardness test. The result showed the different surface hardness average value of metachrylate and silorane based composite resin after application of $40 \%$ hydrogen peroxide. The surface hardness of methacrylate and silorane based composite resins was 41.8 VHN and 33.7 VHN ( $>0.05)$ with t-test, respectively. From this study concluded that there was no significant difference between methacrylate and silorane based composite resins after $40 \%$ hydrogen peroxide application.
\end{abstract}

Keywords: $40 \%$ hydrogen peroxide, surface hardness, methacrylate, silorane

\section{INTRODUCTION}

Interest in the field of esthetic dentistry has become commonplace in today's world and attracts the attention of all ages. ${ }^{1}$ It is proved by the many publications of dentistry journals that deal specifically with this issue. In Indonesia, in line with increasingly evolving thoughts and information, people's insights are increasingly open to aesthetic dentistry. This has become a hot topic in society and makes people pay more attention to aesthetics so that care has been to the stage of care that can beautify the appearance. ${ }^{2}$

The teeth whitening technique is included in esthetic dentistry because it makes the teeth brighter and embellishes one's appearance. This bleaching technique was first used in the late $1870,{ }^{3}$ and continues to be used today. The teeth whitening technique can be classified into bleaching on vital and non-vital teeth and when viewed from the technique consisting of in-office bleaching and home bleaching. 
Over the last few years vital home teeth whitening techniques have attracted both patients and dentists because of their success rate, and ease of use. But recently, in-office teeth whitening products that use high concentrations of hydrogen peroxide were re-introduced. The latter procedure, one of which uses $30 \%$ to $40 \%$ hydrogen peroxide, has the advantage of being fully within the dentist's control and is more effective because of the faster bleaching process. ${ }^{4}$

Bleaching techniques are generally applied to six anterior teeth and may be found in composite fillings of classes I, III, IV, V, and veins on those teeth. ${ }^{4}$ As with bleaching techniques, restorations with composite resins are also included into esthetic dentistry, since it can be used to restore lost tooth structure and modify contours and colors that resemble original teeth so as to improve one's appearance. ${ }^{5}$

The composite consists of four main components, namely the maktriks which are organic components, fillers or the so-called fillers which are an inorganic components, coupling agents for embedding matrices and fillers and system of accelerators. ${ }^{6,5}$ Dental restorative materials have improved over the last decade, including composite restorations. ${ }^{7}$ Key strategies have been carried out since 1950 by composite product companies to reduce leakage or shrinkage in composite restorations by increasing filler load, and efforts to improve physical properties have focused on developing monomers that are organic components contained in the matrix and new technology of filler. ${ }^{8}$ The development of this monomer is silorane. This silorane-based composite has a "ring-opening" monomer which at the time of polymerization of this ring-shaped monomer will open, elongate and attach to each other. The result is a significantly smaller shrinkage volume than a methacrylate-based composite. Methacrylate is also a monomer contained in a composite matrix mostly used in composite resins. ${ }^{9}$ Metallized composites of methacrylate have linearly shaped monomers, which when polymerization extends and attaches to each other, resulting in reduced volume resulting in increase in depreciation. ${ }^{9}$

Many studies have reported on the effect of teeth whitening on composite restorations. Obtained a decrease in hardness in flowable composites after a teeth whitening technique. ${ }^{10}$ Several studies have also been conducted to compare the physical properties of metallic and silorane based composites, one of which is comparing the value of surface hardness of composite restorations. Decrease in hardness or softening is one of the important properties of a restoration of physical properties ${ }^{11}$ and these physical properties can help predict the vulnerability of restorative materials to damage during mastication. ${ }^{12}$

The purpose of this study was to observe the difference of surface hardness between methacrylate and silorane based composite resin after application of $40 \%$ hydrogen peroxide invitro.

\section{METHODS}

The type of research conducted was pure experimental in-vitro.

The study population was metallic and silorane based composite resin. The samples were 36 composite resin specimens consisting of 18 methacrylic-based specimens and 18 siloranebased specimens. Determination of the size of this sample is based on the formula to test the difference of two average with the formula of $n=$ $2 \mathrm{~S} 2\left(\mathrm{Z}_{\mathrm{a}}+\mathrm{Z}_{\mathrm{B}}\right)^{2} / \mathrm{d}^{2}$.

By choosing $95 \%$ as the confidence level $\left(Z_{a}=1.96\right)$ and the power test of $80 \%\left(Z_{B}=0.84\right)$ and deviation standard size $(\mathrm{S})$ and $\mathrm{d}=$ magnitude of average difference of surface hardness of resin obtained from Wattanapayungkul and Yap which used the largest $S d(S=4.68)$ and $d=3$. Based on the formula of the sample size is obtained $n=$ 18 per group. The research unit was a composite Vickers Hardness Number (VHN) measured on Vickers Microhardness Tester.

To support this research, several tools and materials used in the manufacture of specimens, application of teeth whitening, and measurement of surface hardness of the material. The tools needed in the research were light curing unit, composite mold, timing, tweezers, composite restoration equipment, measuring cups, composite resin mold, Vickers Microhardness Tester, Ultrasonic cleaner, Glass Lab. Materials required in the study were methacrylate-based composite 
resin of Filtek ${ }^{\circledR}$ Z350, silorane-based composite resin of Filtek $^{\circledR}$ P90, 40\% Hydrogen Peroxide, distilled water, Mylar ${ }^{\circledR}$ matrix, absorbent paper, and artificial saliva.

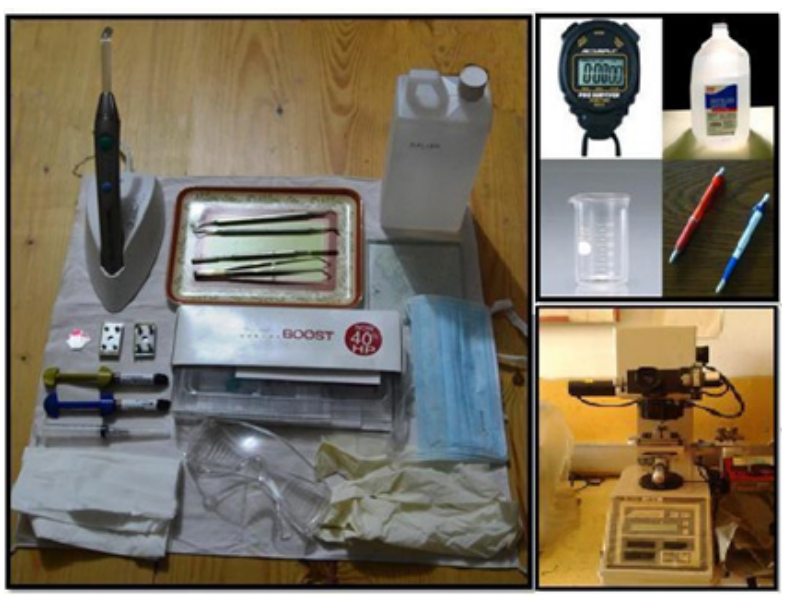

Figure 1. Tools and materials

The working procedure of the research wa the manufacture of specimens (Composite resins prepared according to the instructions of the plant were inserted into a $6 \mathrm{~mm}$ diameter diskshaped aluminum discs with the thickness of $3 \mathrm{~mm}$ based on mylar matrix, composite resin cavities covered with mylar matrix, composite resin polymerized by light-unit unit for 20 seconds, then composite resin specimens divided into 2 groups, 18 specimens each). The application of hydrogen peroxide (Control group: immerse the specimens in artificial saliva for 24 hours, remove and then rinse the specimens with water, cleaning using ultrasonic cleaner for 5 minutes, dry the specimens. Treatment group: immerse the specimens on artificial saliva for 24 hours, lift then rinse the specimens with water, purge using ultrasonic cleaner for 5 minutes, dry the specimens, apply hydrogen peroxide $40 \%$ according to the manufacturer's instructions on the surface of the composite resin, wait for 20 minutes, then rinse the specimens with water, continue cleaning with ultrasonic cleaner for 5 minutes and dry).

Surface of the tested specimen was dried with absorbent paper. Then measured hardness values of composite restorative materials by using Vickers Microhardness Tester. The procedure of using the tool includes placing the sample on the preparatory table, adjusting the focus by raising or lowering the elevating handle, indenting it by placing the indenter just above the sample for 15 seconds with $0.1 \mathrm{~kg}$ load by turning the turret, press start (wait until the light turns off), rotate the turret back to magnification first, measure $d_{1}$ (diagonal length 1 ) by rotating the left knobs and then rotate the right knobs, press $d$-input, then measure $d_{2}$, then get $d_{1}, d_{2}$, and hardness Vickers Number, lastly do three test in a different place.

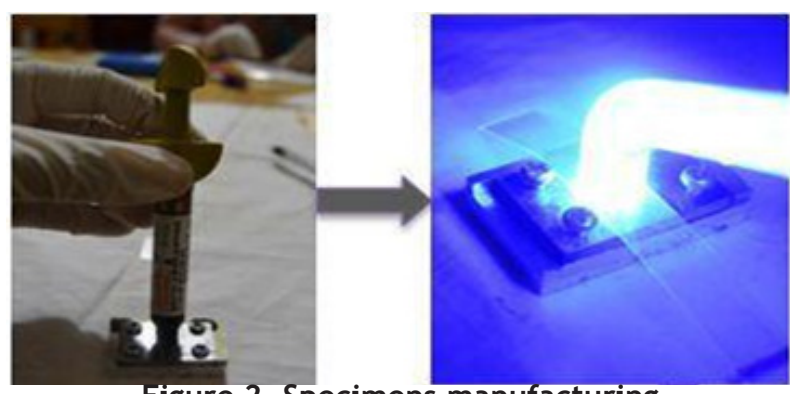

Figure 2. Specimens manufacturing
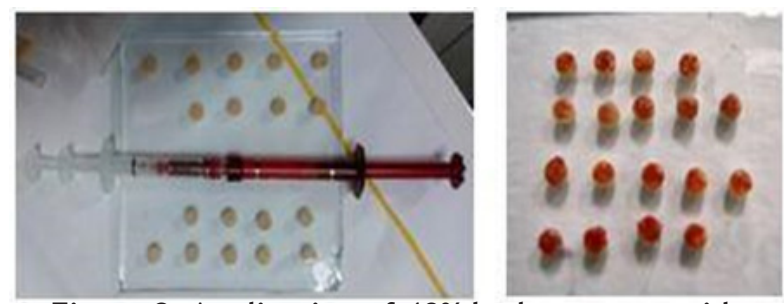

Figure 3. Application of $40 \%$ hydrogen peroxide

\section{RESULTS}

The study was conducted on 36 samples, with 18 groups of methacrylate and 18 groups of silorane, and subdivided into 9 control groups and 9 treatment groups. Each group was immersed in artificial saliva for 24 hours, then in the direct control group tested for hardness and in the treatment group was applied 40\% hydrogen peroxide for 20 minutes then tested the hardness. Hardness testing was performed on one side of the specimen using a microvickers hardness tester. The results showed that each sample experienced a difference in hardness value with a smaller trend in the application of $40 \%$ hydrogen peroxide.

Table 1 showed the measured values on 18 specimens of methacrylate-based composite resins with mean of hardness in the artificial saliva of $44.1 \mathrm{VHN}$ and experienced a difference in hardness value with a smaller tendency in $40 \%$ hydrogen peroxide application of $41.8 \mathrm{VHN}$. 
Table 1. Measurement on methacrylate group

\begin{tabular}{|c|c|c|}
\hline $\begin{array}{c}\text { Composite } \\
\text { specimen }\end{array}$ & Artifical saliva & $\begin{array}{c}\text { 40\% Hydrogen } \\
\text { Peroxide }\end{array}$ \\
\hline 1 & 46.5 & 37.7 \\
\hline 2 & 42.4 & 45.6 \\
\hline 3 & 48.9 & 42.5 \\
\hline 4 & 43.8 & 41.1 \\
\hline 5 & 40.8 & 38.7 \\
\hline 6 & 49.3 & 44.4 \\
\hline 7 & 42 & 46.7 \\
\hline 8 & 44.5 & 43.7 \\
\hline 9 & 38.4 & 35.5 \\
\hline Average & 44.1 & 41.8 \\
\hline
\end{tabular}

Table 2. Measurement on silorane group

\begin{tabular}{|c|c|c|}
\hline $\begin{array}{c}\text { Composite } \\
\text { specimen }\end{array}$ & Artifical saliva & $\begin{array}{c}\text { 40\% Hydrogen } \\
\text { Peroxide }\end{array}$ \\
\hline 1 & 32.5 & 34.5 \\
\hline 2 & 37.6 & 35.6 \\
\hline 3 & 36.7 & 33.7 \\
\hline 4 & 32.3 & 39.4 \\
\hline 5 & 34.5 & 32 \\
\hline 6 & 32 & 39.6 \\
\hline 7 & 33.7 & 28.1 \\
\hline 8 & 32.7 & 32.9 \\
\hline 9 & 33.3 & 27.8 \\
\hline Average & 33,9 & 33,7 \\
\hline
\end{tabular}

Table 2 showed the value of measurements on 18 specimens of silorane-based composite resins with mean of hardness in artificial saliva of 33.9 VHN and experienced different hardness values with less tendency in $40 \%$ hydrogen peroxide applications of $33.7 \mathrm{VHN}$.

Table 3. Results Mean Value of Hardness Resin Composite Based Methacrylate and Silorane in Artificial Saliva and Applications of Hydrogen Peroxide 40\%

\begin{tabular}{|l|c|c|}
\hline \multicolumn{1}{|c|}{ Specimen } & VHN average & Std. dev. \\
\hline $\begin{array}{l}\text { Methacry- } \\
\text { late-Artificial } \\
\text { saliva }\end{array}$ & 44.1 & 3.6 \\
\hline $\begin{array}{l}\text { Methacry- } \\
\text { late-Hydrogen } \\
\text { Peroxide 40\% }\end{array}$ & 41.8 & 3.8 \\
\hline $\begin{array}{l}\text { Silorane-Artifi- } \\
\text { cial saliva }\end{array}$ & 33.9 & 2.0 \\
\hline $\begin{array}{l}\text { Silorane-Hydro- } \\
\text { gen Peroxide } \\
\text { 40\% }\end{array}$ & 33.7 & 4.2 \\
\hline
\end{tabular}

Table 3 showed the mean comparison values of methacrylic and silorane based resins in artificial saliva and $40 \%$ hydrogen peroxide applications. It was found that the mean difference of metacrylic composite resin hardness in artificial saliva and hydrogen peroxide application was $40 \%$ greater than that of silorane composite resin.

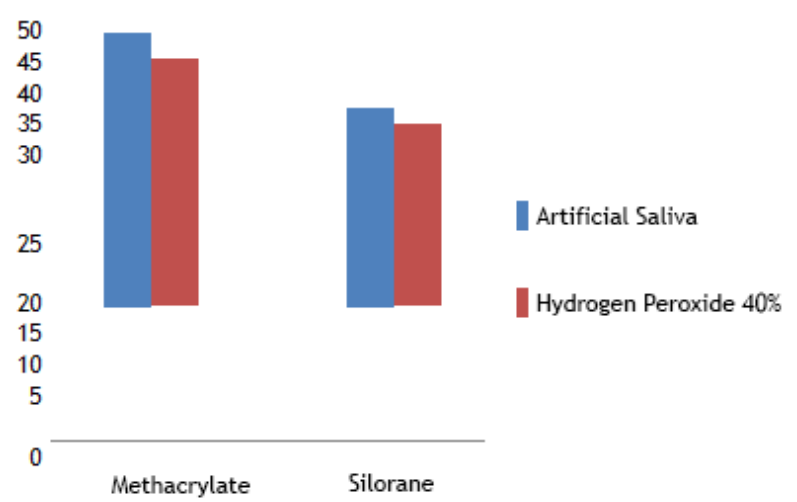

Figure 4. Average value of surface hardness value of methacrylate and silorane-based composites.

Based on Figure 4 the tendency of hardness values to be smaller is greatest in the methacrylate-based composite resin which was applied by $40 \%$ hydrogen peroxide. To determine the significance of the statistical test of the difference in mean of hardness between artificial saliva application and hydrogen peroxide, the first step is to test the data normality based on Shapiro Wilk test, the result was shown in Table 4.

Based on the normality test the average surface hardness data of both base material and treatment showed insignificant results $(p>$ 0.05), showed that the data came from normal distributed population, so for the purposes of different test analysis, used parametric statistic with $\mathrm{T}$ test.

Based on Table 5, the result of statistical test using $T$ test shows that the difference of methacrylate and silorane hardness values in treatment with artificial saliva and hydrogen peroxide $40 \%$ is not significant, for methacrylate based material $p=0,209$ and silorane base material $p=0,905$. However, the difference of mehtacrylate and silorane hardness values with artificial saliva application was statistically significant with $\mathrm{p}$ value $<0.001$; and with a hydrogen peroxide application of $40 \%$ with a value of $p=0.001$. It appeared that the use of silorane base material in both artificial saliva treatment and $40 \%$ hydrogen 
peroxide were having a mean surface hardness of the resin lower when compared with the use of silorane base material.

Based on the statistical test results, there were no significant difference between methacrylate-artificial saliva, methacrylatehydrogen peroxide $40 \%$, silorane-artificial saliva, and silorane-hydrogen peroxide $40 \%$.

Table 4. Normality test result of surface hardness of methacrylate and silorane based composites

\begin{tabular}{|l|c|c|c|c|}
\hline \multirow{2}{*}{$\begin{array}{c}\text { Surface hardness } \\
\text { (VHN) }\end{array}$} & \multicolumn{2}{|c|}{ Statistical Measurement } & \multirow{2}{*}{$\begin{array}{c}\text { Normality } \\
\text { data test } \\
\text { (p-value) }\end{array}$} \\
\cline { 2 - 4 } & & SD & Range & 0.820 \\
\hline Methacrylate-Artificial saliva & 44.1 & 3.6 & $38.4-49.3$ & 0.766 \\
\hline Methacrylate-Hydrogen peroxide 40\% & 41.8 & 3.8 & $35.5-46.7$ & 0.082 \\
\hline Silorane-Artificial saliva & 33.9 & 2.0 & $32.0-37.6$ & 0.505 \\
\hline Silorane-Hydrogen peroxide 40\% & 33.7 & 4.2 & $27.8-39.6$ & 0.6 \\
\hline \multicolumn{2}{|c|}{ Based on Shapiro-Wilk test }
\end{tabular}

Table 5. Comparison result of the surface hardness of methacrylate and silorane based composites

\begin{tabular}{|c|c|c|c|c|}
\hline \multirow{2}{*}{ Surface hardness } & \multicolumn{2}{|c|}{ Treatment } & t-test & $\mathrm{p}$-value \\
\cline { 2 - 4 } & Artificial saliva & Hydrogen peroxide 40\% & \\
\hline $\begin{array}{c}\text { Methacrylate } \\
\mathrm{X}_{\text {SD }}\end{array}$ & $44.1(3.6)$ & $41.8(3.8)$ & 1.308 & 0.209 \\
\hline $\begin{array}{c}\text { Silorane } \\
\mathrm{X}_{\text {SD }}\end{array}$ & $33.9(2.6)$ & $33.7(4.2)$ & 0.122 & 0.905 \\
\hline t-test & $\begin{array}{c}7.311 \\
\mathrm{p}<0.001\end{array}$ & $\begin{array}{c}4.251 \\
\mathrm{p}=0.001\end{array}$ & \\
\hline \multicolumn{3}{|c|}{ Notes: $\mathrm{p}<0.05$ significant; $\mathrm{p}>0.05$ not significant } \\
\hline
\end{tabular}

\section{DISCUSSION}

In a study of 18 specimens of methacrylate-based composite resin and 18 silorane specimens there was a change in the value of surface hardness with a smaller trend after the insignificant application of hydrogen peroxide $40 \%$. In the teeth whitening process, $\mathrm{H}_{2} \mathrm{O}_{2}$ will produce $\mathrm{HO}_{2}$ • (peryhydroxyl) which is a strong free radical and $\mathrm{O}_{2} \cdot$ as a weak free radical. Once $\mathrm{HO}_{2}$ is formed in large quantities, this free radical will react with the unsaturated bonds of the electron bond. This leads to interference in electron conjugation and changes in energy absorption in organic molecules, in addition to changes in the molecular weight of the organic matter of the tooth that reflects the discolorizing specific light waves in the material with a lower molecular weight and the reduced molecules reflecting light, thus forming molecules organic yag with a lighter color. ${ }^{13}$

In composite restorations, Bailey in 1992, and Hannig in 2006 explained that tooth whitening agents can reduce composite hardness because hydrogen peroxide oxidizes and generates free radicals. ${ }^{15,16}$ This hydrogen peroxide breaks down into $\mathrm{H}^{+}$ions which are unstable free radicals. The free radicals formed will interact with the composite organic molecule that is the matrix and break the cyclic carbon bonds found in Bis-GMA. ${ }^{14,16,15,17}$ The reaction occurring in this composite is similar to that occurring in the tooth enamel during the teeth whitening process. The double bond of carbon in the cyclic chain will be broken into a single chain. This process continues until there is complete oxidation. This condition causes the cyclic bis-GMA to weaken and degrade so that the composite hardness will decrease..$^{18,15,19}$ Besides attacking the carbon chain bonds on the resin matrix, free radicals also attack the bond on the coupling agent. Peryhydroxyl which is a weak acid will break the bond of siloxane into silanol bond. Breaking of the siloxane bond between the coupling agent and the filler will lead to the release of the filler particles and a decrease in the hardness of the surface of the composite resin. This was supported by research that says that the chemical process of teeth whitening will accelerate the degradation of hydrolytic resin 
composite. ${ }^{20}$

In Table 3, the mean values of hardness of silicone-based composite resin were smaller than those of methacrylate-based composite resin, supported by the research of Lien and Vandawalle in 2009 on the physical properties of siloranebased composite resins and the research of Ilie and Hickel investigated the mechanical properties of the silorane-based macro, micro, and nano resins with the resultant surface hardness of silorane-based resins lower when compared with methacrylate.

Table 5 showed the difference in the value of hardness with smaller inclinations greater in methacrylate than silorane. In the methacrylate base material this is due to the bis-GMA cyclic degradation mechanism in the methacrylatebased composite matrix by hydrogen peroxide, but no literature has yet been made about the effect of the hydrogen peroxide on the silorane matrix. The resulting difference in hardness values in artificial saliva applications and the small application of hydrogen peroxide to the silorane matrix may have a stronger matrix-filler bond than the methacrylate matrix-filler bond.

Several studies have suggested the effect of in-office bleaching on surface hardness of new composite resins. ${ }^{15,21,4}$ Polydorou in 2006 reported that the influence tooth whitening on surface texture depends on the material and time. ${ }^{22}$ Other research claimed that the teeth whitening agent not only softens the surface of the material restoration but also softens the deeper layers. ${ }^{15}$

\section{CONCLUSION}

From this study concluded that there was no significant difference between methacrylate and silorane based composite resins after $40 \%$ hydrogen peroxide application.

\section{REFERENCES}

1. Rotstein I, Lehr Z, Gedalia I. Effect of bleaching agents on inorganic components of human dentin and cementum. J Endod. 1992 Jun;18(6):290-3.

2. Dental $n$ Dental [homepage on internet]. Wigiyanto. 2011. Perkembangan Kedokteran Gigi Estetik di Indonesia [cited 2011 Oct]; [about 2 screens]. Available from: http:// dentalndental.com/?p=427

3. Fasanaro TS. Bleaching teeth: History, chemicals and methods used for common tooth discolorations. J Esthet Dent. 1992 MayJun;4(3):71-8.

4. Yap AU, Wattanapayungkul P. Effects of inoffice tooth whiteners on hardness of toothcolored restoratives. Oper Dent. 2002 MarApr;27(2):137-41.

5. Sakaguchi RL, Powers JM. Craig's Restorative Dental Material. 12th ed. St. Louis: MosbyElsevier; 2006. p. 191-4.

6. Albers HF. Tooth-Colored Restoratives Principles And Techniques. 9th ed. Ontario: BC Decker Inc.; 2002. p. 111-24.

7. Kugel G, Perry R. Direct composite resins: an update. Compend Contin Educ Dent.2002 Jul;23(7): 593-6, 598, 600 passim; quiz 608.

8. Lien W, Vandewalle KS. Physical properties of a new silorane-based restorative system. Dent Mater. 2010 Apr;26(4):337-44.

9. 3M ESPE. 2007. Filtek silorane. 3M ESPE: p. 1-40.

10. Gurgan S, Yalcin F. The effect of 2 different bleaching regimens on the suraface roughness and hardness of tooth-colored restorative materials. Quintessence Int. 2007 Feb;38(2):e83-7.

11. Stewart MA, Gladwin MA, Bagby MD. Clinical Aspects of Dental Materials. 3rd ed. Philadelphia: Wolters Kluwer Health/ Lippincott Williams \& Wilkins; 2009. p. 55-64, 212-8.

12. Albers HF. Tooth-Colored Restoratives Principles And Techniques. 9th ed. Ontario: BC Decker Inc.; 2002. p. 111-24.

13. Gandaatmaja D, Mulyawati E, Halim HS, Widyastuti W. Pengaruh perbedaan jenis resin komposit dan konsentrasi bahan hidrogen peroksida pada perubahan kekasaran permukaan resin komposit setelah prosedur in office bleaching. J. Ked Gi.2010;1(3):129-34.

14. Bailey SJ, Swift EJ Jr. Effects of home bleaching products on composite resins. Quintessence Int. 1992 Jul;23(7):489-94.

15. Hannig C, Duong S, Becker K, Brunner E, Kahler E, Attin T. Effect of bleaching on subsurface micro-hardness of composite and polyacid modified composite. Dent Mater. 
2007 Feb;23(2):198-203.

16. Goldstein RE, Garber DA. Complete Dental Bleaching. 1st ed. Chicago: Quintessence Publishing Company; 1995. p. 25-34, 57-60.

17. Polydorou O, Hellwig E, Auschill TM. The effect of at-home bleaching on the microhardness of six esthetic restorative materials. J Am Dent Assoc. 2007 Jul;138(7):978-84; quiz 1022.

18. Ferracane JL. Hygroscopic and hydrolitic effects in dental polymer networks. Dent Mater. 2006 Mar;22(3):211-22.

19. Callister WD. Material Science and Engineering: An Introduction. 1st ed. St Louis, Hoboken: John Wiley \& Sons, Inc.; 1994. p. 130.
20. Efek hidrogen peroksida $38 \%$ terhadap kekerasan permukaan resin komposit "supra nano" dan nano hybrid [minor thesis]. Jakarta: UI; 2010.

21. Polydorou O, Beiter J, Konig A, Hellwig E, Kummerer K. Effect of bleaching on the elution of monomers from modern dental composite materials. Dent Mater.2009 Feb;25(2): p. 25460.

22. Polydorou O, Hellwig E, Auschill TM. The effect of different bleaching agents on the surface texture of restorative materials. Oper Dent. 2006 Jul-Aug;31(4):473-80. 